\title{
Khulu' as Evidence of Women Equality Right in Islam
}

\author{
Qurrotul Ainiyah \\ Sekolah Tinggi Ilmu Tarbiyah Al Urwatul Wutsqo \\ Jombang, Indonesia \\ q_ainiy@yahoo.co.id
}

\author{
Julianne Kamelia Riza \\ Sekolah Tinggi Ilmu Tarbiyah Al Urwatul Wutsqo \\ Jombang, Indonesia
}

\begin{abstract}
Human is leader in the world created by Allah and filled all they needs. In carrying out their noble role, human is provided right, obligation, and the law which rules their life. By placing the Allah law as the highest value, means Islam respects for human right. Allah puts the law based on principles of easy to apply and appropriate with human capabilities, and so with marriage as basic right for each person. Islamic law regulates household life is also accompanied right and obligation to make sakinah, mawaddah, and rohmah family. This can be terminated by last alternative (divorce) however, when it can't be maintained anymore. The divorce right in Islam is not for husband only, but wives are also having right to propose divorcing to their husbands. This study is library research; the data is taken from research books and articles. This research describes the equality right between men and women or husband and wife in divorce law. This research concludes that divorce is the last alternative way can be done when there is no peace anymore or divorce is considered to be able to avoid damage though Allah hates it. Islam gives the equal right to the husband and wife who have initiative to file a divorce, though with $t$ unequal terms and legal consequences.
\end{abstract}

\section{Keywords: Khulu’, Women Equality Right, Islam, Divorce}

\section{INTRODUCTION}

Human being is organism that grows and reproduces (regeneration). Human regeneration is based on binding rules formed in the specific institution called marriage in Islam, then creating a household or family. It is expected to be able to create sakinah, mawaddah, and rohmah family until death. However, in the household life does not rule out the possibility of a dispute between husband and wife that can no longer be maintained, and resulting in divorce. Islam permits divorce as an emergency way, or the last alternative which can be taken, if there is no peace anymore, it means that they are permissible. However, Allah hates too much.

Basically, divorce is husbands' right, but Islam gives women opportunity who wants to file a divorce known as khulu' with several requirements must be fulfilled by the wife. It shows that Islam provides equal rights for women in terms of divorce though with different portion.

\section{LITERATURE REVIEW}

\section{A. Human Right}

Human right is the basic right that is close to every human being treated in accordance with the nature of humanity. If it is not implemented, the humanity existence is incomplete .
These rights are laid on equality in all of treatment on the law regardless the discrimination of race, color, sex, language, religion, or political and other views. Human right are universal, applies to all human beings without looking at their strata and social level, economic status, different religion, gender, or any others.

As individuals, every human being has desire instinctively to be free from force, making choice, expressing opinion, and choosing beliefs. As social beings, the freedom they have is limited by other individual right which may have different cultures, races, ethnicities, religions, sex, social positions, and any other. These cause ones' human rights is not absolutely free, it is restricted by other people rights. The implementation of human right therefore, must be balanced with their obligations; means that they can guide their human right when carry out their obligation as social beings.

The source of human right is known as natural law. It is a concept of general moral principle of justice system that applies to all humanity recognized and believed mankind. The progress of human right concept is explained in the human right convention. It is an international agreement which binds legally many countries and provides policy measure has to be met by government. The countries which ratify of convention have to guarantee that the citizen human right is protected by the convention. In 1948, the United Nations issued the Universal Declaration of Human Rights, which explained this right could not be ignored and violated by all human beings. This declaration is a moral milestone in the history of the nation Because of the lack of law enforcement, the Universal Declaration of Human Rights principles must be transformed into laws to give them juridical status for the countries that ratify them. This transformation produces two conventions that distinguish two types of human rights, such as civil and political rights, the two conventions forms the International Bill on Human Rights.

In Indonesia, human rights are regulated in the law of the Republic of Indonesia number 39 of 1999, it is included family rights and continues descent, the right to develop themselves, obtain justice, personal freedom, security, welfare, participate in government, even the rights for women and children are regulated in separate articles. In addition, the Indonesian government also has laws governing family life, which is the law number 23 of 2004 concerning the elimination of domestic violence. This shows that the human rights respect and enforcement in Indonesia are protected by the government through the law. 
Regarding human rights, the United Nations regulates it in the Convention on the Elimination of All Discrimination Forms against Women or the Convention on the Elimination of all Forms of Discrimination Against Women which is then abbreviated as CEDAW. The substantive provisions of CEDAW are based on the equality principles, substantive equality, non-discrimination and accountability, and state responsibility about the women status and rights from various fields, namely:

1) Implementation in all fields covered in the definition of discrimination, such as gender based violence. (article 1 of CEDAW);

2) Legislative apparatus accountability, executive policy and law enforcement (article 2 and all article of CEDAW);

3) All the fields, especially politic, social, economic, and culture (article 3 of CEDAW);

4) Special measures to accelerate de facto equality, and specific measures applies to protect pregnancy (Ps. 4);

5) Change social and cultural behavior patterns, prejudices, habits and other practices based on inferiority or superiority of one the sex. Family education regarding pregnancy as a social function and the responsibility of men and women to raise children (Ps.5);

6) Women trafficking and exploitation of prostitution (Ps. 4);

7) Equality in the fields of politics, community life, the right to choose and be elected, the right to participate in government, and non-government associations (Ps.7);

8) Representing the government at the international level and participating in the international organizations activities of (Ps.8);

9) The right to gain, change or maintain his citizenship and the nationality of his child (Ps.9);

10)Education field (Ps.10);

11)Employment field (Ps.11);

12)Fields of health, family planning, pregnancy, childbirth and postpartum (Ps.12);

13)Economics and social field, especially family allowances, bank loans, and recreational activities, sports and culture (Ps.13);

14) Rural women in all fields (Ps.14);

15)In the field of law, legal skills in contracts, managing property, judicial processes, mobility and choosing a place to live (Ps.15);

16) In marriage fields, family, rights to children and marriage property (Ps. 16)

There are 5 women rights in CEDAW, namely:

1) The right of Employment, every woman has the right to have equal employment opportunities to work as men, including opportunities in the selection process, work facilities, benefits, receiving equal wages, getting paid leave, including maternity leave, not be dismissed due to pregnancy or marital status.

2) Right in the health field, women have the right to get a guarantee of health services, family planning, pregnancy, childbirth, and post-natal care.

3) Right of education, women have right to have opportunity to take part in education by eliminating the stereotypes of the men and women roles in all levels and forms of education and various facilities including getting scholarships.

4) Rights of marriage and family that is the equal rights in choosing a potential partner based on agreement of both parties, there must not be forced marriage, have the same rights and responsibilities, either parents to children, and married couples.

5) Rights of public and political life, namely the right to choose and be elected, participate in the formulation of government policies until their implementation.

Women's rights then in Indonesia are regulated in article 45-51 of the Republic of Indonesia law number 39/1999, including political, citizenship, education rights, carrying out legal acts, and rights in marriage. Regarding women's rights in marriage are regulated in articles 50-51, namely;

Ps 50 : Women who are mature and/or married have the right to do their own legal actions, unless determined by their religious law.

Ps 51 (1) : A wife in marital relationship has the same rights and responsibilities to her husband for all matters relating to her marital life, relations with her children and ownership rights and shared assets management.

(2) : when their marriage breakup, a woman has the same rights and responsibilities as her former husband for all matters relating to her children by paying attention to the best interests of the child.

(3) : After the termination of marriage, a woman has the same rights as her former husband over all matters relating to shared assets without reducing children's rights in accordance with statutory.

In article of 30-34 law no. 1/1974 concerning about marriage law in Indonesia stated, that the husband and wife bear a noble obligation to uphold the household which is the basis of the community structure. The rights and position of them are balanced in domestic life and in the community. Each of them has the right to carry out legal actions.

\section{B. Human Right in Islam}

Islam rules humanity to follow Allah guidance Almighty during his life. Because the life purpose in the world is to worship, and obey to Allah only. Islam does not recognize the dichotomy between temporal and spiritual life. Basically the Islamic structure is Religio Politic. As Iqbal says that the state is only an attempt to achieve spiritual goals in human organizations. The branching of human unity into spiritual life is complementary and totally implemented together. As explained in the Qur'an, al-Baqarah surah (2): 107, 255, alNajm surah (53): 31-32. 
The concept of human right in Islam is shown in AK. Brohi research as quoted by Atfar Gaufari : "In the totality of Islam, human obligations to Allah is also obligations to other individual. So paradoxically, the rights of each individual are protected by all obligations under the ilahi law. In terms of terminology and sociology, there are differences human right concepts in Islam and the western. Human rights based on Islamic conception are human activities as Allah servants and kholifah in the earth. Meanwhile, in western, it is determined by public rules for the creation of peace and security in the universe.

Dr. Syeh Syaukat Hussain says that there are two categories of human obligations under Allah guidance, namely huquuqulloh (the rights of Allah), this is human obligations towards Allah SWT manifested in various rituals worship, and huququl Ibad (human rights) is human obligations to others and to other Allah creatures. Thus in Islam any responsibility held by human towards his neighbor has been established by Allah SWT as a right.

There are two kinds of human rights in huququl 'Ibaad, they are legal right, that is human rights which its existence held by a country (Islam), and human right which its existence can't be held directly by a country (Islam) or called moral rights. A typical aspect of human rights in Islam is the presence of other people who can forgive violations of rights. It means that the state must be bound to give punishment to those who violate other people rights. Except those who are persecuted has forgiven the perpetrator. This is reinforced by the prophet hadith which explains about the criteria of bankrupt humans. A bankrupt people is not a human who is loser in trading, but they who face Allah bringing worship merit and good deeds however, they are cruel to other people, take a way property rights and torture others, so that the reward is given to people who have been persecuted, and if it is not enough, then the people sin who was persecuted was charged to that person.

The implementation of Islamic teaching (law) is for world and hereafter happiness, then structured in Ibadat, Muamalat, Munakahat dan Jinayat. These four things are a description of Allah's mercy and compassion which includes everything that upholds human rights. This is evidenced by the recognition of the five basic human rights must be protected regardless the differences of status, language, gender, nation, beliefs and culture. These basic rights are the life right (life protection), religious rights (religious protection), the right to think and opinion (intellectual protection), the right to means of life (property protection), and the right to descent (offspring protection). These five basic protections, then becomes the basis of the laws formation. and the law then regulates and protects human life. It can be said, the implementation of Islamic law is certain to protect at least one of these basic rights.

\subsection{Khulu'}

Khulu' is one of the way to break marriage ties. Khulu' comes from the word khala' means release, khala'a ats-tsauba means take off clothes, because in Islam, wife is a husband cloth, and husband is also wife cloth. According to fiqih, Khulu' is a divorce bought by wife from her husband who doesn't make his wife happy, known as thalaq tebus (Javanese). In this case the wife compensate herself from her husband by returning everything has been received as dowry or the wife separating herself from her husband by giving compensate to him. The permissibility of khulu' for wife is because of syar'i reasons, that is reasons that cause damage to her religion, such as apostate husband, husband committing misbehave or polytheism, husband prohibiting and preventing his wife from carrying out religious obligations, husband force his wife to commit immorality to Allah and so forth. This explanation is based on the Qur'an al-Baqarah surah (2): 229. And Islam forbid khulu' who has no reason, as the prophet hadith:

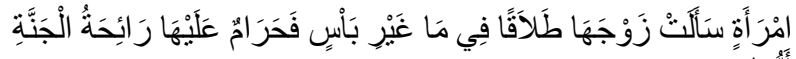

"Whoever a woman who asks her husband to divorce her without any reason, then it is prohibited for her to smell out the heaven".

There are some Khulu' laws, namely obligatory, prohibited, allowed, makruh, and sunnah. Khulu' is obligatory when the husband does not give livelihood, and sex to his wife, so they make his wife tortured. Khulu' is prohibited, when it is able to cause misery for his wife and children. Khulu' is allowed for the reason of a need that allows the wife take that way. The Khulu' will be makruh, if there is no a need allows wife to do it. And the last Khulu' is sunnah because both wife and husband will achieve goodness. The wisdom contained in the Khulu' Shari'at is to reject the danger, namely if the husband and wife schism has peaked and they cannot maintain their rights and obligations, then the Khulu ' based on Allah ways can be done to reject the hostility occurrence, besides, it is to uphold Allah laws.

\section{The Women's Right EQUALITY IN KHULU'}

Marriage is intended to form sakinah, mawaddah and rahmah family. In realizing it, all parts (husband and wife) have to understand and conduct their rights and obligations. However, it is possible there will be problems in marriage which cannot be solved except by divorce. Divorce is a case which be able to be done but Allah really hates it (makruh). it is emergency way, the last alternative after they cannot find other way, because divorce is contrary to marriage as a strong agreement.

In Islamic law, marriage, divorce, and reconcilement are husbands' right. It means that husband is the one who intends and pledges the case. Husband therefore, express ijab qabul of marriage, thalaq, and sighot ruju' (reconcilement), and they are still valid though the wife disagree about it. The statement is contrary to human basic rights given by Allah, they are race, ethnicity, nation, religion and gender. All of them are cannot be violated. As cited in article of 50, law number 39/1999 namely: the mature/married women have right to do their own legal actions, unless determined by their religious law.

The statement of women who are mature and / or married have the right to do their own legal actions.....shows that mature women have rights to do their own legal actions on her own behalf, such as marriage, thalaq, rujuk, etc. they have rights to determine with whom they will get married, and there is no force to do. Wife is also able to propose the divorce without waiting to be divorced by her husband. The wife may object to be reconciliation when she doesn't want to be by her former husband. it means they have the equal rights and 
position in the law, they have equally rights to do their own legal actions.

Furthermore, the statement of above article is...... unless determined by their religious law. The statement gives explanation that the implementation of conducting mature women rights is limited religious provisions. The provisions of religious law must be considered, however, when there is a different rule in it. It means that religious law is more binding than the law number 39/1999. For example the husband utter about "the word thalaq", once the husband says the word, so the thalaq is legitimate. However, it does not apply to wives, although the wife says thalaq many times to her husband, there will not be divorce at all. Because the law regulated by Islam is thalaq is the husband right.

The solution to wife who wants to propose the divorce is khulu', this is a wife separated herself from her husband by giving compensation. This divorce process is from the wife. The application of this process is different between khulu' and thalaq are:

1. Wife is the one who wants and propose (claim) divorce.

2. Husband is one who utters sighot thalaq.

3. The availability of iwadh given by wife to the husband as replacement of husband readiness to divorce his wife.

4. Husband does not have reconcilement right when the wife proposes khulu', they must do a new contract of marriage when they want to get reconcilement.

5. The wife must do iddah either in thalaq or khulu'.

Table 1. Distinction of Thalaq and Khulu'

\begin{tabular}{cccc}
\hline No & Criteria & Thalaq & Khulu' \\
\hline 1 & $\begin{array}{c}\text { The one who } \\
\text { proposes divorce } \\
\text { The one who } \\
\text { divorce }\end{array}$ & Husband & Wife \\
2 & Iwadh & Not available & Avand \\
3 & Ruju' & Available & Not Available \\
4 & &
\end{tabular}

Based on the above explanation, it shows that Islam provides the same portion for husband or wife in term of divorce, they both have right to propose divorce with different term (thalaq and khulu') with rule and different logic consequences because of different law. Anyway the difference is proportional from the point of view of the regulation rules, the rights and obligations, their responsibilities in the household.

\section{CONCLUSION}

Khulu' is a divorce for wife wants to separate from the husband by giving compensation to him with certain conditions. The khulu' implementation is one of the ways for the wife to use her human rights that is legal actions for her. The women right in implementing their legal actions is limited by religious provisions. The religious law is more binding and obeyed. So the khulu' is done in accordance with religious law, which is the wife who wants to propose divorce, but her husband, must divorce her. It means they have equality right in proposing divorce, not in dropping the divorce.

\section{REFERENCES}

[1] Ahmed, Ishaq, Konstitusionalisme, HAM dan reformasi Islam dalam Rekonstruksi Shari'ah II, Kritik, Konsep, penjelajahan lain, terj. Farid Wajdi, Yogyakarta : LKIS, 1996.

[2] Al-Jaziri, Al-Fiqh ala Al-Madzahib Al-Arba'ah, Vol. IV, Bairut: Dar Ihya' al-Turots al-'Arabi, 1996.

[3] Convention Watch, Pusat Kajian Wanita dan Gender, Universitas Indonesia, Hak Azasi Perempuan, Instrumen Hukum Untuk Mewujudkan Keadilan Gender. Jakarta : Yayasan Obor Indonesia, 2007.

[4] Ishaq Ahmed, Konstitusionalisme, HAM dan reformasi Islam dalam Rekonstruksi Shari’ah II, Kritik, Konsep, penjelajahan lain, terj. Farid Wajdi, Yogyakarta : LKIS, 1996.

[5] Qurrotul Ainiyah, Keadilan Gender Dalam Islam, Konvensi PBB dalam Perspektif Mazhab Shafi'i, Malang: Intrans Publishing, 2015.

[6] Sayyid Sabiq, Fikih Sunnah, jilid 8, alih bahasa : Drs. Mohammad Thalib, (Bandung : Pt. Al-Ma'arif, 1980.

[7] Syeh Syaukat Hussein, Human Right in Islam, terj. Abdur Rochim, Jakarta: Gema Insani Pers, 1996. 